\title{
Retraction Note to: Adapting project management method and ANFIS strategy for variables selection and analyzing wind turbine wake effect
}

\section{Dalibor Petković ${ }^{1}$ S Siti Hafizah Ab Hamid ${ }^{2} \cdot$ Žarko Ćojbašić $^{1} \cdot$ Nenad T. Pavlović ${ }^{1}$}

Published online: 28 May 2020

(c) Springer Nature B.V. 2020

\section{Correction to: Nat Hazards (2014) 74:463-475 https://doi.org/10.1007/s11069-014-1189-1}

The Editor-in-Chief has retracted this article [1] because validity of the content of this article cannot be verified. This article showed evidence of substantial text overlap (most notably with the articles cited (2-5) and peer review and authorship manipulation. None of the authors responded to correspondence about this retraction.

\section{References}

1. Petković D, Ab Hamid SH, Ćojbašić Ž et al (2014) Nat Hazards 74:463. https://doi.org/10.1007/s1106 9-014-1189-1

2. Basser H, Shamshirband S, Karami H et al (2014) Nat Hazards 73:1393. https://doi.org/10.1007/s1106 9-014-1140-5

3. Gonzalez JS, Rodriguez AGG, Mora JC et al (2010) Renew Energy 35(8):1671. https://doi. org/10.1016/j.renene.2010.01.010

4. Floricel S, Bonneau C, Aubry M, Sergi V (2014) Int J Project Manag 32(7):1091. https://doi. org/10.1016/j.ijproman.2014.02.008

5. Petković D, Ćojbašić Ž, Lukic S (2013) Expert Syst Appl 40:4490. https://doi.org/10.1016/j. eswa.2013.01.055

Publisher's Note Springer Nature remains neutral with regard to jurisdictional claims in published maps and institutional affiliations.

The original article can be found online at https://doi.org/10.1007/s11069-014-1189-1.

Dalibor Petković

dalibortc@gmail.com

1 Department for Mechatronics and Control, Faculty of Mechanical Engineering, University of Niš, Aleksandra Medvedeva 14, Niš 18000, Serbia

2 Faculty of Computer Science and Information Technology, University of Malaya, 50603 Kuala Lumpur, Malaysia 